\title{
Recurrent oral ulceration treated with Mysteclin: a controlled study
}

\author{
A M DENMAN, A A SCHIFF
}

British Medical fournal, 1979, 1, 1248-1249

\section{Summary and conclusions}

Twenty patients with recurrent oral ulceration participated in a placebo-controlled, double-blind trial of Mysteclin syrup (tetracycline hydrochloride and amphotericin) used as a mouthwash. Though a small, consistent improvement occurred with placebo, there was a significant reduction in mean pair scores and numbers of new ulcers recorded daily during the active-treatment periods, the effect lasting for at least four weeks after treatment was stopped.

In contrast to topical steroid preparations, Mysteclin syrup is efficacious when begun at any stage of the disorder and is not associated with adverse systemic effects.

\section{Introduction}

Numerous aetiological factors have been implicated in recurrent aphthous ulceration of the mouth, including infective agents such as Streptococcus sanguis. There is thus some rationale for the widely recommended use ${ }^{1}$ of the broad-spectrum antibioticantifungal syrup Mysteclin (tetracycline hydrochloride $125 \mathrm{mg}$ and amphotericin $25 \mathrm{mg}$ per $5 \mathrm{ml}$ ). We, however, report what we believe to be the first controlled trial of Mysteclin in aphthous ulcers.

Northwick Park Hospital, Harrow, Middlesex HA1 3UJ

A M DENMAN, FRCP, consultant physician

E R Squibb and Sons Ltd, Twickenham TW1 3QT

A A SCHIFF, MRCS, LRCP, deputy head of medical division

\section{Method}

Patients attending the outpatient clinic of the division of immunological medicine at this hospital were seen by AMD; those with mouth ulcers of the aphthous type ${ }^{2}$ were asked to record for four months on forms provided daily pain scores (severity scale $0-3$ ) and the number of new ulcers appearing daily. No medication was prescribed during the period. Patients returning at the end of the four months with adequate records who were still troubled by ulcers were asked to participate in a comparative trial of two mouthwashes. Fully informed consent was obtained from each patient and the trial was approved by the hospital's ethical committee.

Patients were allocated at random on a double-blind basis to a sequence of four weeks with treatment, four weeks without treatment, a further four weeks with treatment, and a final four weeks without treatment. Treatment was either $5 \mathrm{ml}$ Mysteclin syrup or $5 \mathrm{ml}$ matching placebo syrup used three times daily, the order being randomised. The medicine was swilled around the mouth for a few minutes and then spat out. Patients continued to keep daily records of pain and new ulcers throughout the 16 weeks of the trial.

\section{Results}

The first 20 patients who kept satisfactory pretrial records participated in and completed the trial. There were 10 women and 10 men, and their age range was $16-75$ (mean 25) years. Seven patients were suffering from Behçet's syndrome, defined as mucocutaneous lesions associated with at least one major system disease-for example, arthritis, skin manifestations, or colitis. The remaining patients included one with coeliac disease receiving a gluten-free diet, one with rheumatoid arthritis taking salicylates, one with discoid lupus erythematosus, and one with rheumatic heart disease. Tables I and II give the results.

The mean pain scores were significantly $(P<0.01)$ lower during the active-treatment than placebo periods, and significantly fewer new ulcers $(P<0.05)$ were recorded. During the course of the study pain scores significantly decreased $(P<0.01)$ in patients taking the active treatment but not in those taking placebo. Significantly fewer ulcers

TABLE I-Mean and standard error (SE) of pain scores and numbers of new ulcers recorded by patients $(n=20)$ completing trial

\begin{tabular}{|c|c|c|c|c|c|c|c|c|c|c|}
\hline & \multicolumn{2}{|c|}{ Pretrial period } & \multicolumn{4}{|c|}{ Treatment periods } & \multicolumn{4}{|c|}{ Post-treatment periods } \\
\hline & Mean & SE & $\underset{\text { (mean) }}{\text { Mysteclin }}$ & $\begin{array}{l}\text { Placebo } \\
\text { (mean) }\end{array}$ & $\begin{array}{c}\text { SE of } \\
\text { difference }\end{array}$ & $\mathrm{P}^{*}$ & $\underset{(\text { mean) }}{\text { Mysteclin }}$ & $\begin{array}{c}\text { Placebo } \\
\text { (mean) }\end{array}$ & $\begin{array}{c}\text { SE of } \\
\text { difference }\end{array}$ & $P^{*}$ \\
\hline $\begin{array}{l}\text { Pain scores } \\
\text { No of new ulcers }\end{array}$ & $\begin{array}{r}0.93 \\
15 \cdot 25\end{array}$ & $\begin{array}{l}0 \cdot 10 \\
2 \cdot 06\end{array}$ & $\begin{array}{l}0 \cdot 31 \\
2 \cdot 70\end{array}$ & $\begin{array}{l}0 \cdot 68 \\
9 \cdot 35\end{array}$ & $\begin{array}{l}0.13 \\
2 \cdot 39\end{array}$ & $\begin{array}{l}<0.01 \\
<0.05\end{array}$ & $\begin{array}{l}0.40 \\
3 \cdot 35\end{array}$ & $\begin{array}{l}0.63 \\
7.55\end{array}$ & $\begin{array}{l}0.17 \\
1.60\end{array}$ & $\begin{array}{l}\text { NS } \\
<0.05\end{array}$ \\
\hline
\end{tabular}

* Significance of difference between treatments assessed by analysis of variance.

NS $=$ Not significant

TABLE II-Mean changes in pain scores and numbers of new ulcers recorded (arithmetical differences) during consecutive periods of trial. Results expressed with standard error

\begin{tabular}{|c|c|c|c|c|c|c|}
\hline & \multicolumn{2}{|c|}{$\begin{array}{l}\text { All patients } \\
(n=20)\end{array}$} & \multicolumn{2}{|c|}{$\begin{array}{l}\text { Patients with Behçet's syndrome } \\
\qquad(\mathrm{n}=7)\end{array}$} & \multicolumn{2}{|c|}{$\begin{array}{l}\text { Patients with other diseases } \\
\qquad(\mathrm{n}=13)\end{array}$} \\
\hline & Mean & SE & Mean & $S E$ & Mean & $\mathrm{SE}$ \\
\hline $\begin{array}{l}\text { Period before Mysteclin minus period on Mysteclin }\left\{\begin{array}{l}\text { Pain } \\
\text { Ulcers } \\
\text { Period before placebo minus period on placebo } \\
\text { Period on Mysteclin minus period after Mysteclin } \\
\text { Ulcers }\end{array}\right. \\
\begin{array}{l}\text { Pain } \\
\text { Ulcers }\end{array} \\
\begin{array}{l}\text { Pain } \\
\text { Ulcers }\end{array}\end{array}$ & $\begin{array}{l}0.43^{* *} \\
7.90^{* * *} \\
0.12 \\
1.00 \\
-0.09 \\
-0.65 \\
0.05 \\
1.80\end{array}$ & $\begin{array}{l}0.12 \\
1.96 \\
0.14 \\
2.58 \\
0.13 \\
1.22 \\
0.07 \\
1.41\end{array}$ & $\begin{array}{r}0.47 \\
7.42 \\
0.10 \\
0.57 \\
-0.44 \\
-1.71 \\
0.12 \\
0.57\end{array}$ & $\begin{array}{l}0 \cdot 23 \\
3.70 \\
0.32 \\
3.56 \\
0 \cdot 35 \\
3 \cdot 38 \\
0.07 \\
2 \cdot 43\end{array}$ & $\begin{array}{l}0.41^{*} \\
8.15^{* *} \\
0.13 \\
1.23 \\
0.10 \\
-0.08 \\
0.01 \\
3.08\end{array}$ & $\begin{array}{l}0 \cdot 14 \\
2 \cdot 24 \\
0 \cdot 14 \\
3 \cdot 57 \\
0 \cdot 09 \\
0 \cdot 67 \\
0.09 \\
1 \cdot 70\end{array}$ \\
\hline
\end{tabular}

Significance of difference from zero: ${ }^{*} \mathrm{P}<0.05 ;{ }^{*} \mathrm{P}<0.01 ;{ }^{* *} \mathrm{P}<0.001$. 
also occurred in the four weeks after active treatment was stopped than in the four weeks after placebo treatment $(P<0.05)$.

None of the order effects was found to be significant.

\section{Comment}

The therapeutic effect of Mysteclin syrup clearly exceeded the consistent, small improvement seen with placebo. Topical steroid preparations are the other main form of treatment for aphthous ulcers, but these need to be started at the prodromal stage, before frank ulceration develops, and dosage must be carefully restricted to avoid systemic effects. Our findings show that Mysteclin is efficacious irrespective of the phase of the disorder and suggest that the improvement is maintained for at least four weeks after treatment is stopped. Further work will determine whether complete remission can be produced by prolonging treatment enough to eliminate the bacteria responsible for putative antigenic cross-reactions.

We are grateful to Dr John Anderson, of the department of statistics, University of Newcastle upon Tyne, for the statistical analyses.

\section{References}

${ }^{1}$ British Medical fournal, 1974, 3, 757.

2 Scully, C, and Lehner, T, Dental Update, 1978, 5, 379.

(Accepted 20 March 1979)

\section{SHORT REPORTS}

\section{High-density-lipoprotein cholesterol in the Maasai of East Africa: a cautionary note}

The Maasai are a Nilo-Hamitic tribe well known for their low incidence of cardiovascular disease. ${ }^{1}$ Many reports have shown high serum cholesterol concentrations to be related to an increased risk of coronary artery disease, and the Maasai were found to have a significantly lower mean serum cholesterol concentration than an agematched group of Europeans. ${ }^{2}$ It has recently been suggested that high-density lipoproteins (HDLs) have an inverse relation to the risk of coronary artery disease. ${ }^{3}$ We have compared the concentrations of HDL cholesterol in the Maasai with those in a group of healthy men attending a screening centre in London.

\section{Subjects, methods, and results}

Blood samples were taken from 37 tribal and 20 non-tribal Maasai men living in Southern Kenya in August 1977, and from 317 European men attending for routine health screening in London in August 1978. The total serum cholesterol (TC) concentrations of the Maasai were estimated by Searle Laboratories using a Lieberman-Burchard method without extraction, whereas those of the Europeans were measured at the Radcliffe Infirmary, Oxford, using the same method but with extraction. All HDL samples were measured in Oxford with a heparin-manganese precipitation method. The Maasai $\mathrm{HDL}$ samples were stored at $-20^{\circ} \mathrm{C}$ for six months before analysis. To allow for the non-comparability of cholesterol measurements between Maasai and Europeans, a correction factor based on the correlation between measurements made at the two laboratories was applied to the cholesterol value of each of the Maasai. There were no significant differences between tribal and non-tribal Maasai in mean HDL concentration, total cholesterol concentration, or HDL:TC ratio. The results were therefore combined to form a single Maasai sample.

The mean serum HDL concentration in the Maasai was significantly lower than in the Europeans (table). As the mean serum cholesterol concentration was also significantly lower, however, the HDL:TC ratio did not differ significantly between the two groups.

\section{Comment}

In view of the reported inverse association between HDL and coronary heart disease we were surprised to find such low HDL values in the Maasai. Even when the low total serum cholesterol

Mean $( \pm S D)$ serum high-density lipoprotein $(H D L)$ and total cholesterol $(T C)$ concentrations and HDL:TC ratios in populations studied

\begin{tabular}{lccc}
\hline & $\begin{array}{c}\mathrm{HDL} \\
(\mathrm{mmol} / \mathrm{l})\end{array}$ & $\begin{array}{c}\text { TC } \\
(\mathrm{mmol} / \mathrm{l})\end{array}$ & $\begin{array}{c}\text { HDL:TC ratio } \\
(\%)\end{array}$ \\
\hline Maasai $(\mathrm{n}=57)$ & $1 \cdot 05 \pm 0 \cdot 31$ & $4 \cdot 77 \pm 0 \cdot 81$ & $22 \cdot 63 \pm 7 \cdot 71$ \\
Europeans $(\mathrm{n}=317)$ & $1 \cdot 40 \pm 0 \cdot 29 *$ & $6 \cdot 21 \pm 1 \cdot 14^{*}$ & $23.34 \pm 6 \cdot 77(\mathrm{NS})$ \\
\hline
\end{tabular}

*Significance of difference between means $(t$ test): $\mathrm{P}<0.001$

Conversion: SI to traditional units-HDL and TC: $1 \mathrm{mmol} / 1 \approx 38.6 \mathrm{mg} / 100 \mathrm{ml}$. concentrations of the Maasai were taken into account by considering the ratio of HDL to total cholesterol, there was no significant difference between the Maasai and Europeans. The values reported here are much lower than those found in Nigerian men ${ }^{4}$ and rural black South Africans, ${ }^{5}$ whose mean HDL:TC ratios are about twice that found in the Maasai. Further work on populations with differing incidences of heart disease is thus required, but at present it seems that the relation between coronary heart disease and indices such as HDL or the HDL:TC ratio is far from straightforward.

We thank Dr R A Moore, department of clinical biochemistry, Radcliffe Infirmary, Oxford, and Dr Alan Craig, Searle Laboratories, High Wycombe, and their staff for the biochemical assays. This work was supported by grants from the British Heart Foundation and the Boise Fund, Oxford.

${ }^{1}$ Mann, G V, et al, fournal of Atherosclerosis Research, 1964, 4, 289.

${ }^{2}$ Day, J, et al, Atherosclerosis, 1976, 23, 357.

${ }^{3}$ Miller, G J, and Miller, N E, Lancet, 1975, 1, 16.

4 Onitiri, A C, Sander, M, and Boyo, A E, Clinica Chimica Acta, 1977, 81, 57.

5 Walker, A R P, and Walker, B F, British Medical fournal, 1978, 2, 1336.

(Accepted 26 February 1979)

BUPA Medical Research, London WC1

DAVID ROBINSON, MSC, ARCS, research statistician

PETER WILLIAMS, $\mathrm{BM}, \mathrm{BCH}$, assistant to research director

London NW3

JOSÉ DAY, MB, MRCGP, general practitioner

\section{Unprocessed bran causing intestinal obstruction}

Unprocessed bran has been widely advocated by the medical profession and the lay press for the management of constipation, the irritable colon syndrome, and diverticular disease. We report a patient who developed intestinal obstruction due to excessive intake of bran.

\section{Case report}

A 53-year-old housewife was admitted to hospital complaining of nausea, cramping abdominal pains, distension, and incontinence of faeces for three days. She had a 20 -year history of chronic anxiety requiring treatment with imipramine in doses of up to $150 \mathrm{mg} /$ day. Over this period she had had chronic constipation for which she took two Coloxyl with Danthron tablets (dioctyl sodium sulphosuccinate $50 \mathrm{mg}$ with 1,8-dihydroxy anthraquinone $50 \mathrm{mg}$ ) nightly.

A year before admission she began taking about $20 \mathrm{~g} /$ day of unprocessed bran. Subsequent improvement in her bowel actions encouraged her to increase her intake progressively, culminating in consumption of 160-200 g/ 